\title{
Pengaruh Penggunaan Pendekatan Pembelajaran Kuantum Dan Media Kartu Kata Bergambar Terhadap Keterampilan Membaca Nyaring pada Anak Tunarungu
}

\author{
Handik Indarwati ${ }^{1}$ \\ 1) SDLB Banjarsari Wetan, Banjarsari Wetan Dagangan Madiun, Indonesia \\ e-mail: ${ }^{1)}$ handikindarwati@yahoo.com
}

\begin{abstract}
Abstrak
Tujuan dari penelitian ini adalah untuk mengetahui apakah terdapat pengaruh penggunaan pendekatan pembelajaran kuantum dan media kartu kata bergambar terhadap keterampilan membaca nyaring pada anak tunarungu. Sampel penelitian yang diambil adalah siswa kelas IV B SDLB Negeri Banjarsari Wetan Kabupaten Madiun berjumlah 60 siswa. Penelitian ini menggunakan metode quasi eksperimen atau eksperiman semu. Data penelitian diambil dari hasil observasi terhadap siswa, wawancara dengan guru kelas, dan tes tertulis untuk mengukur keterampilan membaca nyaring anak tunarungu. Hasil penelitian menunjukkan adanya pengaruh penggunaan media kartu kata bergambar terhadap keterampilan membaca nyaring anak tunarungu, adanya pengaruh penggunaan pendekatan metode pembelajaran quantum, dan adanya interaksi antara penggunaan media kartu kata bergambar dan metode pembelajaran quantum dalam peningkatan keterampilan membaca nyaring pada anak tunarungu.
\end{abstract}

Kata kunci: pembelajaran kuantum; media kartu kata bergambar; membaca nyaring; anak tunarungu

\begin{abstract}
The purpose of this study is to determine whether there is an effect of using quantum learning and picture-word cards on students' reading aloud mastery or not. The sample of the study taken was the fourth grade of deaf students at SDLB Banjarsari Wetan, Madiun Regency, about sixty students. This study used quasi experimental design. The data were taken from the observation of students, interview with teachers and written tests to measure deaf students' reading aloud mastery. The results of the study show there is a significant effect of using quantum learning and picture-word cards on students' reading aloud mastery and there is an interaction between using quantum learning and picture-word cards on students' reading aloud mastery.
\end{abstract}

Keywords Quantum learning; picture-word cards; reading aloud; deaf students

\section{Pendahuluan}

Perkembangan pendidikan saat ini menuntut siswa mampu menyerap informasi dengan baik. Baik dengan cara mendengarkan berita, berkomunikasi dengan orang lain maupun pengalaman hidup. Anak Berkebutuhan Khusus ( $A B K$ ) merupakan istilah lain menggantikan kata "Anak Luar Biasa (ALB)" yang menandakan adanya kelainan khusus. Anak berkebutuhan khusus mempunyai karakteristik yang berbeda antara satudengan yang lainnya (Yuniati, 2013). Bagi anak tunarungu, menyerap informasi memiliki tantangan tersendiri karena mereka kekurangan atau kehilangan kemampuan pendengarannya. Anak tunarungu cenderung mengalihkan pengamatannya melalui indera visual. Untuk mengoptimalkan indera visual anak tunarungu dapat dilakukan 
dengan cara mengembangkan keterampilan membacanya. Salah satunya melalui metode membaca nyaring.

Suasana belajar yang kondusif dan menyenangkan merupakan faktor penting dalam menunjang keberhasilan pembelajaran. Untuk mengembangkan keterampilan membaca nyaring, guru harus memiliki kreatifitas dalam menentukan pendekatan yang sesuai untuk meningkatkan prestasi belajar anak. Perlu kemampuan guru untuk menerapkan metode pembelajaran yang tepat jika dalam pelaksanaan proses pembelajaran ditemui adanya kendala-kendala yang pada akhirnya akan menjadi masalah di kelas. Hal ini mengingat jika masalah dibiarkan berlarut-larut bukan tidak mungkin akan menyebabkan pencapaian proses pembelajaran menjadi tidak maksimal (Siswandi, 2006). Ahsin (2016) guru bahasa Indonesia di tiap sekolah disarankan untuk dapat mengajarkan pelajaran dengan menarik dan mengubah cara belajar dari metode ceramah atau konvensional dengan penggunaan media dan metode pembalajaran yang lebih inovatif. Dalam melaksanakan proses pembelajaran guru untuk selalu menggunakan media pembelajaran yang menarik dan juga menggunakan metode pembelajaran yang inovatif, seperti metode quantum learning agar hasil kemampuan belajar siswa lebih meningkat.

Mata pelajaran bahasa Indonesia merupakan mata pelajaran yang menekankan pada aspek belajar berkomunikasi. Oleh karena itu aktivitas pembelajaran diarahkan untuk meningkatkan kemampuan siswa dalam berkomunikasi dengan bahasa Indonesia yang baik dan benar. Dalam pembelajaran Bahasa juga mencakup aspek mendengarkan, berbicara, membaca, dan menulis. Keempat aspek tersebut sebaiknya mendapat porsi yang seimbang. Maka akan tepat kalau kemampuan berkomunikasi dapat ditingkatkan melalui pembelajaran mata pelajaran Bahasa Indonesia. Meningkatnya keterampilan berkomunikasi diharapkan juga dapat meningkatkan aktivitas dalam proses pembelajaran di kelas karena kemampuan berkomunikasi tidak hanya dibutuhkan dalam mata pelajaran Bahasa Indonesia tetapi juga mata pelajaran lain. Oleh karena itu mata pelajaran Bahasa Indonesia tentunya akan berdampak pada mata pelajaran lain baik yang menyangkut ilmu-ilmu social maupun sains. Bahasa sebagai alat komunikasi dapat digunakan untuk berbagai macam fungsi sesuai dengan apa yang ingin disampaikan oleh penutur, misalnya untuk menyampaikan informasi faktual (mengidentifikasikan, melaporkan, menanyakan, dan mengoreksi); menyatakan sikap intelektual (menyatakan setuju atau tidak setuju, menyanggah, dan sebagainya); menyatakan sikap emosional senang, tak senang, harapan, kepuasan, dan sebagainya); menyatakan sikap moral (meminta maaf, menyatakan penyesalan, penghargaan, dan sebagainya); menyatakan perintah mengajak, mengundang, memperingatkan, dan sebagainya); untuk bersosialisasi (menyapa, memperkenalkan diri, menyampaikan selamat, meminta perhatian, dan sebagainya)

Pembelajaran kuantum adalah pengubahan belajar yang meriah dengan segala suasananya. Quantum learning ialah kiat, petunjuk, strategi, dan seluruh proses belajar yang dapat mempertajam pemahaman dan daya ingat, serta membuat belajar sebagai suatu proses yang menyenangkan dan bermanfaat. Beberapa teknik yang dikemukakan merupakan teknik meningkatkan kemampuan diri yang sudah populer dan umum digunakan. "Quantum learning mencakup aspek-aspek penting dalam program neurolinguistik (NLP), yaitu suatu penelitian tentang bagaimana otak mengatur informasi. Program ini meneliti hubungan antara bahasa dan perilaku dan dapat 
digunakan untuk menciptakan jalinan pengertian siswa dan guru. Para pendidik dengan pengetahuan NLP mengetahui bagaimana menggunakan bahasa yang positif untuk meningkatkan tindakan-tindakan posistif - faktor penting untuk merangsang fungsi otak yang paling efektif. Semua ini dapat pula menunjukkan dan menciptakan gaya belajar terbaik dari setiap orang (De Porter dan Hernacki, 1992). Dengan media kartu kata bergambar, suasana dalam kelas akan menjadi hidup. Siswa akan tertarik dengan gambar yang mereka lihat, sehingga dapat merangsang anak untuk lebih aktif dan agresif dalam mengucapkan kata sesuai dengan gambar yang mereka lihat, bahkan di dalam mengucapkan kata siswa cenderung untuk bersaing dengan temannya. Beberapa hal yang penting dicatat dalam quantum learning adalah sebagai berikut. Para siswa dikenali tentang "kekuatan pikiran" yang tak terbatas. Ditegaskan bahwa otak manusia mempunyai potensi yang sama dengan yang dimilliki oleh Albert Einstein. Selain itu, dipaparkan tentang bukti fisik dan ilmiah yang memerikan bagaimana proses otak itu bekerja. Melalui hasil penelitian Global Learning, dikenalkan bahwa proses belajar itu mirip bekerjanya otak seorang anak 6-7 tahun yang seperti spons menyerap berbagai fakta, sifat-sifat fisik, dan kerumitan bahasa yang kacau dengan "cara yang menyenangkan dan bebas stres" (DePorter, 2010; Cross, et.all, 2015).

Gangguan pada organ pendengaran bias terjadi pada telinga luar, tengah, maupun bagian dalam. Letak gangguan secara anatomis tersebut mengklasifikasikan tunarungu menjadi 2 tipe konduktif, sensorineural, dan campuran. Tunarungu tipe konduktif diakibatkan adanya gangguan pada telinga luar dan tengah, sedangkan tunarungu sensorineural diakibatkan gangguan pada telinga bagian dalam serta syaraf pendengaran. Adapun tunarungu campuran merupakan perpaduan antara tipe konduktif dan sensorineural. Dampak langsung dari ketunarunguan adalah terhambatnya komunikasi verbal/lisan, baik secara ekspresif (berbicara) maupun reseptif (memahami pembicaraan orang lain), sehingga sulit berkomunikasi dengan lingkungan orang mendengar yang lazim menggunakan bahasa verbal sebagai alat komunikasi. Hambatan dalam berkomunikasi tersebut, berakibat juga pada hambatan dalam proses pendidikan dan pembelajaran anak tunarungu. Namun demikian anak tunarungu memiliki potensi untuk belajar berbicara dan berbahasa (Hernawati, 2007).

Menurut Sugiarti (2016) dasar dan tujuan pendidikan tuna rungu sama dengan dasar dan tujuan pendidikan bagi siswa normal. Selain tujuan pendidikan umum, pendidikan siswa tunarungu juga mempunyai tujuan pendidikan khusus. Hal ini disebabkan karena siswa Tuna rungu mempunyai karakteristik khusus yang berbeda dengan siswa normal pada umumnya. Tujuan pendidikan khusus untuk siswa tunarungu yaitu; menambah kesadaran siswa dalam mengenal lingkungan alamiah dan lingkungan sosial, mengembangkan kecakapan dasar yang sangat diperlukan untuk berdiri sendiri, memiliki pengetahuan dasar untuk bekal dalam kehidupan sehari-hari.

Membaca memegang peranan penting dalam kehidupan sehari-hari, tanpa membaca seseorang bisa menjadi buta terhadap berbagai perkembangan dan kemajuan dalam berbagai bidang keilmuan, dan informasi yang didapat sebagian besar diperoleh melalui membaca. Oleh karena itu ketrampilan membaca sangat penting untuk selalu ditingkatkan. Membaca merupakan suatu keterampilan untuk mendapatkan informasi, untuk mengikuti atau mendapatkan suatu ilmu yang berkaitan dengan apa yang dibaca. Dengan membaca kita akan mengetahui kejadian atau peristiwa dan perkembangan dari bahan yang kita baca (Aulia, 2012).

Pengaruh Penggunaan Pendekatan Pembelajaran Kuantum Dan Media... (Handik Indarwati) 
Permasalahan utama yang dihadapi oleh anak tunarungu adalah miskin akan bahasa dan kosa kata sehingga anak kurang bisa memahami setiap bahasa yang ada dalam lingkungannya yang menjadikan anak sulit menangkap informasi yang ada, namun indera visualnya masih bisa dimanfaatkan jadi solusi yang tepat untuk anak tunarungu agar bisa memperoleh informasi dan berkomunikasi dengan lingkungannya yaitu dengan mengoptimalkan indera visualnya sebagai pengganti indera pendengaran, dan dengan cara membacalah anak tunarungu dapat dilatih untuk berkomunikasi baik secara langsung maupun tidak langsung.

\section{Metode Penelitian}

Penelitian ini dilaksanakan di SDLB Negeri Banjarsari Wetan dengan sampel 60 siswa. Teknik sampling yang digunakan adalah multyple stage random sampling atau pengambilan sampel acak sederhana. Kelas ekperimen terdiri dari 60 siswa terbagi menjadi: (1) 15 siswa mendapat keterampilan membaca nyaring dengan non Metode Kuantum learning dan non media kartu kata bergambar, (2) 15 siswa mendapat keterampilan membaca nyaring dengan non Metode Kuantum learning dan media kartu kata bergambar, (3) 15 siswa mendapat keterampilan membaca nyaring dengan Metode Kuantum learning dan non media kartu kata bergambar, dan (4) 15 siswa mendapat keterampilan membaca nyaring dengan pendekatan quantum learning dan media kartu kata bergambar.

Peneliti menggunakan teknik pengumpulan data berupa test kemampuan membaca. Penilaian berbentuk angka tes yang telah disajikan dengan kriteria penilaian untuk keterampilan membaca. Data yang dihimpun di analisis menggunakan analisis statistik parametrik dengan menggunakan desain eksperimen faktorial $2 \times 2$, dengan mempertimbangkan subyek atau sampel yang digunakan dalam penelitian.

\section{Hasil dan Pembahasan}

Hasil penelitian dilaporkan melalui dua tahap, yaitu (1) secara deskriptif dan (2) inferensial. Laporan secara deskriptif dilengkapi dengan tabel frekuensi dan histogram. Laporan secara inferensial menyajikan hasil uji asumsi yang berupa uji normalitas dan homogenitas populasi serta hasil analisis dengan anava dua jalan.

Data perbandingan kemampuan membaca nyaring siswa yang diajar dengan metode pembelajaran kuantum dan non kuantum setelah dilakukan analisis deskriptif sebagai berikut:

Tabel 1. Perbandingan Mean Kemampuan Nyaring Siswa yang diajarkan dengan Metode Kuantum dan Non Kuantum

\begin{tabular}{lc}
\hline \multicolumn{1}{c}{ Kelompok } & Rata - rata \\
\hline Siswa yang diajar dengan metode kuantum & 19,20 \\
\hline Siswa yang diajar dengan metode non kuantum & 11,60 \\
\hline
\end{tabular}


Setelah dikelompokkan-kelompokkan sesuai dengan rancangan penelitian, perbandingan mean kemampuan membaca nyaring siswa menggunakan media pembelajaran gambar dan non gambar sebagai berikut:

Table 2. Perbandingan Mean Kemampuan Membaca Nyaring Siswa Yang Diajarkan Dengan Media Gambar dan Non Gambar

\begin{tabular}{lc}
\hline \multicolumn{1}{c}{ Kelompok } & Rata - rata \\
\hline Siswa yang diajar dengan media gambar & 16,00 \\
\hline Siswa yang diajar dengan media non gambar & 14,80 \\
\hline
\end{tabular}

Dari hasil perhitungan menggunakan SPSS release 13 maka didapatkan tabel hasil uji ANAVA tentang perbedaan kemampuan membaca antara siswa yang diajar dengan kuantum dengan siswa yang diajar dengan non kuantum sebagai berikut:

Tabel 3. Hasil uji Anava

Tests of Between-Subjects Effects

Dependent Variable: MEMBACA

\begin{tabular}{|l|r|r|r|r|r|}
\hline Source & $\begin{array}{c}\text { Type III Sum } \\
\text { of Squares }\end{array}$ & df & Mean Square & \multicolumn{1}{|c|}{ F } & \multicolumn{1}{c|}{ Sig. } \\
\hline Corrected Model & $914,667^{a}$ & 3 & 304,889 & 9,758 &, 000 \\
Intercept & 14229,600 & 1 & 14229,600 & 455,417 &, 000 \\
MEDIA & 21,600 & 1 & 21,600 & 4,691 &, 039 \\
METODE & 866,400 & 1 & 866,400 & 27,729 &, 000 \\
MEDIA * METODE & 26,667 & 1 & 26,667 & 3,853 &, 040 \\
Error & 1749,733 & 56 & 31,245 & & \\
Total & 16894,000 & 60 & & & \\
Corrected Total & 2664,400 & 59 & & & \\
\hline
\end{tabular}

a. R Squared $=, 343$ (Adjusted R Squared $=, 308$ )

Dari tabel tersebut didapatkan harga Fhitung sebesar 27,729 sedangkan Ftabel $(1,56)$ sebesar 4,00 dan taraf signifikansi $(P)$ sebesar 0.039. Karena Fhitung $>$ Ftabel, atau 27,729> 4,00 maka Ho ditolak dan Ha diterima, artinya ada pengaruh Kemampuan Membaca Nyaring siswa antara siswa yang diajar dengan metode pembelajaran kuantum dengan siswa yang diajar metode pembelajaran non kuantum. Komunikasi antar anak dapat terjalin dengan baik melalui bahasa, sehingga anak dapat membangun hubungan sosial dalam lingkungan masyarakat, dan tidak mengherankan bahwa bahasa dianggap sebagai salah satu indikator kesuksesan seorang anak. Anak yang dianggap banyak berbicara, kadang merupakan cerminan anak yang cerdas dan aktif. Pemahaman atau penguasaan kosa kata yang didapat berbeda-beda antara anak yang satu dengan anak yang lain. Perkembangan pemerolehan Bahasa anak dari lingkungan keluarga maupun dari lingkungan masyarakat juga berbeda antaranak. Lingkungan keluarga yang berpengetahuan bahasa, akan mendidik anak dan melakukan kebiasaan berbahasa yang dilakukan orang tuanya dalam komunikasi sehari-hari, sehingga anak 
dapat belajar lebih dari satu Bahasa (Rahayu, 2012; Nurdiyanti, 2014; Heriantoko, 2013; Sentis, et.all, 2012).

Perbedaan kemampuan membaca antara siswa yang diajar dengan gambar dengan siswa yang diajar dengan non gambar didapatkan harga Fhitung sebesar 4,691 sedangkan Ftabel $(1,56)$ sebesar 4,00 dan taraf signifikansi $(P)$ sebesar 0.000 . Karena $F_{\text {hitung }}>F_{\text {tabel, }}$ atau 4,691> 4,00 maka Ho ditolak dan Ha diterima, artinya ada pengaruh Kemampuan Membaca Nyaring siswa yang diajar dengan media gambar dengan siswa yang diajar dengan media non gambar. Sugiarti (2012) media Kartu Gambar Berantai ini dapat dikembangkan kepada peserta didik yang mempunyai kelainan atau kebutuhan khusus yang lain selain peserta didik tunarungu.

Hasil Perhitungan Interaksi antara Metode Pembelajaran Kuantum, Metode pembelajaran Non Kuantum dan Media pembelajaran gambar, non gambar erhadap Kemampuan Membaca Nyaring siswa didapatkan harga Fhitung sebesar 4,183 sedangkan Ftabel $(3,56)$ sebesar 2,76 dan taraf signifikansi $(P)$ sebesar 0.040 . Karena $F_{\text {hitung }}>F_{\text {tabel, }}$ atau 3,853>2,76 maka Ho ditolak dan Ha diterima, artinya ada pengaruh Metode Pembelajaran Kuantum dan Media pembelajaran gambar terhadap Kemampuan Membaca Nyaring siswa.

Karena hasil perhitungan Anava menunjukkan bahwa Ho ditolak. Dengan demikian dapat disimpulkan bahwa ada pengaruh media kartu bergambar terhadap keterampilan membaca nyaring anak tunarungu kelas IV di SDLB Negeri Banjarsari Wetan, Kecamatan Dagangan, Kabupaten Madiun. Berdasarkan kenyataan tersebut maka hipotesis alternatif kedua teruji.

Seperti yang dikemukakan oleh DePorter (2003: 3) bahwa pembelajaran kuantum adalah pengubahan belajar yang meriah dengan segala suasananya. Sedangkan ada pendapat lain yang menyatakan bahwa pembelajaran kuantum adalah cara pengubahan berbagai macam-macam interaksi, hubungan dan inspirasi yang ada di dalam dan sekitar momen belajar (Charlotte Shelton, 1998: 1).

Menurut Alwiyah Abdurrohman (1999: 14) Quantum Learning juga diartikansebagai suatu kiat, petunjuk, strategi dan seluruh proses belajar yang dapatmempertajam pemahaman daya ingat, serta belajar sebagai proses yangmenyenangkan dan bermakna. Suatu proses pembelajaran yangmenyenangkan tentu akan memberikan kontribusi pemahaman yang lebihbaik bagi siswa.

Berdasarkan kedua pendapat di atas maka pendekatan pembelajaran kuantum dapat dirumuskan sebagai suatu pendekatan yang menitik beratkan pada pengubahan suasana belajar dan pengelolaan kelas yang kondusif agar suatu proses belajar tersebut menghasilkan siswa yang berprestasi.

Hipotesis alternatif pertama berbunyi "Ada pengaruh penggunaan pendekatan metode pembelajaran kuantum terhadap keterampilan membaca nyaring anak tunarungu kelas IV di SDLB Negeri Banjarsari Wetan, Kecamatan Dagangan, Kabupaten Madiun. Karena hasil perhitungan Anava menunjukkan bahwa Ho ditolak. Dengan demikian dapat disimpulkan bahwa ada pengaruh pendekatan metode pembelajaran kuantum terhadap keterampilan membaca nyaring anak tunarungu kelas IV di SDLB Negeri Banjarsari Wetan, Kecamatan Dagangan, Kabupaten Madiun

Berdasarkan kenyataan tersebut maka dapat dikatakan bahwa dengan adanya metode pembelajaran kuantum yang disesuaikan dengan materi dan tujuan pembelajaran maka akan semakin baik hasil kemampuan membaca siswa. 
Menurut Donald F. Moores (dalam Permanarian Somad dan Tati Hernawati 1996: 27) bahwa orang tuli adalah seseorang yang kehilangan kemampuan mendengar pada tingkat $70 \mathrm{~dB}$ ISO atau lebih sehingga ia tidak dapat mengerti pembicaraan orang lain melalui pendengarannya sendiri, tanpa atau menggunakan alat bantu mendengar. Sedangkan orang kurang dengar adalah seseorang yang kehilangan kemampuan mendengar pada tingkat $35 \mathrm{~dB}$ sampai $69 \mathrm{~dB}$ ISO sehingga ia mengalami kesulitan untuk mengerti pembicaraan orang lain melalui pendengaran sendiri, tanpa atau dengan alat Bantu mendengar.

Menurut Somantri (1996: 74), tunarungu dapat diartikan sebagai suatu keadaan kehilangan pendengaran yang mengakibatkan seseorang tidak dapat menangkap berbagai rangsangan, terutama melalui indera pendengarannya. Menurut Aqila Smart (2010: 34), tunarungu adalah istilah umum yang digunakan untuk menyebutkan kondisi seseorang yang mengalami gangguan dalam indera pendengaran.

Dari beberapa batasan pendapat yang dikemukakan di atas maka anak tunarungu merupakan anak yang mengalami gangguan pendengaran baik seluruh maupun sebagian yang disebabkan ketidak berfungsian organ pendengarannya sehingga tidak dapat menggunakan pendengarannya dalam kehidupan sehari-hari yang membawa dampak terhadap kehidupannya secara komplek.

Kebanyakan anak tunarungu ketika masuk sekolah belum bisa diajak berkomunikasi secara verbal. Mereka juga belum bisa melakukan komunikasi secara tertulis. Komunikasi yang biasa dilakukan anak tunarungu adalah bahasa isyarat sederhana. Adanya disfungsi pendengaran siswa SLB-B di Karanganyar menjadikan pembelajaran bahasa pada mereka mengalami kendala. Sehingga diperlukan strategi tersendiri untuk dapat mengajak mereka belajar membaca (Yuliati, 2017; Mardiana, 2016; Elly, 2013; Heriantoko, 2013; Haidir, 2007). Anak tunarungu merupakan anak yang mengalami gangguan dalam pendengarannya sehingga sulit menerima informasi. Oleh karena itu agar anak tunarungu tetap bisa menerima informasi seperti anak normal lainnya maka jalan yang terbaik yaitu dengan mengoptimalkan indera yang masih berfungsi dan salah satunya adalah indera visual. Dengan indera visual itulah anak tunarungu dapat memperoleh informasi yang mereka butuhkan untuk menambah wawasan dengan cara membaca. Aktivitas fisik yang berkaitan dengan membaca adalah gerak mata dan ketajaman penglihatan. Oleh sebab itu anak tunarungu sangat membutuhkan keterampilan membaca hal itu karena indera yang masih bisa dioptimalkan adalah indera visualnya atau matanya.

Pendekatan pembelajaran kuantum merupakan salah satu pendekatan yang efektif untuk semua jenis usia dalam meningkatkan kemampuan belajar. Media adalah alat bantu yang berfungsi sebagai perantara dalam pembelajaran sehingga dapat membangkitkan motivasi dan rangsangan serta dapat memudahkan siswa di dalam menerima pembelajaran. Kartu kata dapat memberikan kemampuan keterampilan membaca nyaring dalam intonasi, tekanan kata, pemenggalan kata, pemenggalan frasa, dan untuk menemukan kebutuhan pengajaran yang spesifik.

Hipotesis alternatif pertama berbunyi "Ada interaksi antara penggunaan media kartu kata bergambar dan metode pembelajaran kuantum dalam peningkatan keterampilan membaca nyaring. "Karena hasil perhitungan Anava menunjukkan bahwa Ho ditolak. Dengan demikian dapat disimpulkan bahwa ada interaksi antara penggunaan media kartu kata bergambar dan metode pembelajaran kuantum dalam peningkatan

Pengaruh Penggunaan Pendekatan Pembelajaran Kuantum Dan Media... (Handik Indarwati) 
keterampilan membaca nyaringterhadap keterampilan membaca nyaring anak tunarungu kelas IV di SDLB Negeri Banjarsari Wetan, Kecamatan Dagangan, Kabupaten Madiun. Berdasarkan kenyataan tersebut maka hipotesis alternatif kedua teruji.

Melihat kenyataannya disimpulkan bahwa model pembelajaran yang variatif khususnya media kartu kata bergambar dan metode pembelajaran kuantum dapat mempengaruhi hasil kemampuan membaca nyaring siswa khususnya bagi anak tunarungu.

\section{Kesimpulan}

Dari analisis data dan pembahasan diperoleh beberapa kesimpulan bahwa ada pengaruh penggunaan media kartu kata bergambar terhadap keterampilan membaca nyaring anak tunarungu kelas IV di SDLB Negeri Banjarsari Wetan, ada pengaruh penggunaan pendekatan metode pembelajaran quantum terhadap keterampilan membaca nyaring anak tunarungu kelas IV di SDLB Negeri Banjarsari Wetan, dan ada interaksi antara penggunaan media kartu kata bergambar dan metode pembelajaran quantum dalam peningkatan keterampilan membaca nyaringterhadap keterampilan membaca nyaring anak tunarungu kelas IV di SDLB Negeri Banjarsari Wetan.

Dalam pembelajaran yang berhubungan dengan membaca sebaiknya diterapkan teknik-teknik pembelajaran yang menyenangkan bagi siswa. Pendekatan quantum learning khususnya yang mengenai teknik atau cara membaca untuk menghasilkan suatu pemahaman sebaiknya dilatihkan pada siswa khususnya pada anak tunarungu yang hanya mengandalkan sisa pendengarannya untuk mendapatkan suatu informasi. Sebaiknya guru bersikap aktif dan inovatif dalam memilih pendekatan yang sesuai untuk diterapkan pada siswa. Selain itu, ruangan tiap kelas dipisahkan agar siswa tidak merasa terganggu dan bisa berkonsentrasi dalam kegiatan belajar khususnya kegiatan belajar membaca

\section{Daftar Pustaka}

Abdurrahman, M. (2003). Pendidikan Bagi Anak Berkesulitan Belajar. Jakarta: Rineka Cipta.

Ahsin, M. N. (2016). Peningkatan Keterampilan Menulis Karangan Narasi Dengan Menggunakan Media Audiovisual Dan Metode Quantum Learning. Refleksi Edukatika: Jurnal IImiah Kependidikan, 6(2).

Anita, S. (2011). Media Pembelajaran. Surakarta: UNS Press.

Arikunto, S. (2010). Prosedur Penelitian Suatu Pendekatan Ptaktek. Jakarta: Rineka Cipta.

Aulia, R. (2012). Meningkatkan Kemampuan Membaca Pemahaman pada Anak. Tunarungu. Jurnal IImiah Pendidikan Khusus, 1. 
Cross, A. W., Smith, G., \& Smolin, J. A. (2015). Quantum learning robust against noise. Physical Review A, 92(1), 012327.

De Porter, B. et. all. (2003). Quantum Teaching: Mempraktekkan Quantum Learning di Ruang - Ruang Kelas. Terjemahan oleh Ary. Nilandari. Bandung: Kaifa.

DePorter, B., Hernacki, M., \& Abdurrahman, A. (1999). Quantum learning: membiasakan belajar nyaman dan menyenangkan. Penerbit Kaifa.

DePorter, B., Reardon, M., \& Singer-Nourie, S. (2010). Quantum teaching: mempraktikkan quantum learning di ruang-ruang kelas. Kaifa.

Elly, S. N. (2013). Meningkatkan kemampuan membaca kata melalui metode fonetis bagi anak tunagrahita sedang. E-JUPEKhu, 2(2).

Jainiyah, S. (2015). PENERAPAN STRATEGI DIRECT READING THINKING ACTIVITY (DRTA) UNTUK MENINGKATKAN KETERAMPILAN MEMBACA PEMAHAMAN TEMA BERBAGAI PEKERJAAN SISWA KELAS SEKOLAH DASAR. Jurnal Penelitian Pendidikan Guru Sekolah Dasar, 3(1).

Haidir, H. (2007). Pengaruh Strategi Pembelajaran Dan Kemampuan Mengingat Terhadap Hasil Belajar Bahasa Indonesia Siswa SMP Kemala Bhayangkara 1 Medan (Doctoral dissertation, UNIMED).

Hernawati, T. (2007). Pengembangan Kemampuan Berbahasa dan Berbicara Anak Tunarungu. Jurnal JASSI_anakku, 7(1), 101-110.

Heriantoko, B. C. (2013). Peningkatan Kemampuan Membaca Permulaan Dengan Menggunakan Media Permainan Maze Pada Anak Tunagrahita Ringan Kelas li Di Slb/C Tpa Jember. Jurnal Pendidikan Khusus, 1(1).

Hidayat, R. S. (1990). Pengetesan Kemampuan Membaca Secara Komuniktif. Jakarta: Intermasa.

Mardiana, L. (2016). Metode Multisensori Artikulasi Terhadap Kemampuan Membaca Menulis Huruf AI-Qur'an Permulaan Denganmodel At-Tartil Jilid 1 Siswa Tunarungu. Jurnal Pendidikan Khusus, 8(1).

Mashari, I. W. J. H. A. Peningkatan Pembelajaran Iqro'Di SLB Tuna Rungu Sukarame Bandar Lampung Melalui Quantum Learning.

Nazir, M. (2005). Metode Penelitian. Jakarta: Ghalia Indonesia.

Nurgiyantoro, B. (2010). Penilaian Pembelajaran Bahasa. Yogyakarta: BPFE. 
Nurhadi, N. (2010). Membaca Cepat dan Efektif. Bandung: Sinar Baru Algensindo Offset.

Nurhadiyati, A. (2014). Model induktif kata bergambar terhadap keterampilan menulis kalimat dasar anak tunarungu. Jurnal Pendidikan Khusus, 6(6).

Praheto, B. E. (2013). Penerapan quantum learning dengan media permainan puzzle untuk meningkatkan kemampuan membaca aksara jawa pada siswa kelas $3 b$ sd negeri 1 wangon kab. Banyumas (Doctoral dissertation, UNS (Sebelas Maret University)).

Rahayu, O. K. K. (2012). Pemakaian Konjungsi Pada Bahasa Percakapan Anak Usia 79 Tahun Di Desa Pabelan Kecamatan Kartasura Kabupaten Sukoharjo (Doctoral dissertation, Universitas Muhammadiyah Surakarta).

Saleh, S. (1996). Statistik Nonparametrik. Yogyakarta: BPFE-YOGYAKARTA.

Sitohang, R., \& Sembiring, T. A. (2014). Penggunaan Model Quantum Teaching Untuk Meningkatkan Hasil Belajar Siswa Padamata Pelajaran IPS Kelas V SD Negeri No. 040474 Tigaserangkai. JURNAL HANDAYANI PGSD FIP UNIMED, 1(1).

Smart, A. (2010). Anak Cacat Bukan Kiamat. Yogyakarta: Katahati.

Somad, P., dan Hernawati, H. (1996). Ortopedagogik Anak Tuna Rungu. Jakarta: Deptdikbud.

Sudjana. 2002. Desain dan Analisis Eksperimen. Bandung: PT Tarsito.

Sugiarti, S. (2016). Upaya Meningkatkan Kosa Kata Anak Tunarungu Melalui Media Variasi Gambar Pada Siswa Kelas V/B Di SLB Negeri Surakarta. Prosiding IImu Pendidikan, 1(2).

Sugiyono, S. (2012). Metode Penelitian Kuantitatif, Kualitatif dan R\&D. Bandung: Alfabeta.

Sukmadinata, Nana Syaodih. 2005. Metode Penelitian Pendidikan. Bandung: PT Remaja Rosdakarya.

Siswandi, H. J. (2006). Meningkatkan keterampilan berkomunikasi melalui metode diskusi panel dalam mata pelajaran bahasa indonesia di Sekolah Dasar (penelitian tindakan kelas). Jurnal Pendidikan Penabur, 7(5), 24-35.

Sentís, G., Calsamiglia, J., Munoz-Tapia, R., \& Bagan, E. (2012). Quantum learning without quantum memory. Scientific reports, 2, 708.

Tarigan, H. G. (1984). Membaca Sebagai Suatu Keterampilan Berbahasa. Bandung: ANGKASA. 
Yuliati, F. (2017). Penggunaan Kartu 'Superhero'untuk Meningkatkan Kemampuan Membaca Siswa Kelas I SLB B YPALB Karanganyar. Jurnal VARIDIKA, 29(1). 